\title{
DIVERSIFICATION, CEO COMMITMENT, AND FIRM PERFORMANCE
}

\author{
Engelbertha E. Silalahi \\ Faculty of Economics and Business, Atma Jaya Catholic University of Indonesia \\ engelberthaesilalahi@gmail.com \\ Irenius Dwinanto Bimo \\ Faculty of Economics and Business, Atma Jaya Catholic University of Indonesia \\ irenius.dwinanto@atmajaya.ac.id
}

\begin{abstract}
This study examined the effect of diversification strategies on firm performance and the extent to which the chief executive officer (CEO) commitment moderates this relationship. The effect of diversification on firm performance was analyzed in a sample with both above-average and below-average diversification levels. The sample consisted of 76 manufacturing companies listed on the Indonesia Stock Exchange (IDX) from 2007 to 2018, which were analyzed using panel data regression with a balanced panel. Tobin's $Q$ was utilized to measure firm performance, compounded with three measures of diversification strategies: entropy index, Herfindahl index, and the number of segments. The results show that diversification leads to lower firm performance, whereas CEO commitment eliminates the negative influence of diversification on company performance in all measurement models (i.e., entropy, Herfindahl index, and the number of segments). Accordingly, the negative effect of diversification strategies and consistent CEO commitment were observed among the samples with high and low diversification levels.
\end{abstract}

Keywords: diversification, firm performance, corporate governance, CEO commitment

\section{INTRODUCTION}

The implementation of diversification strategies to boost company performance has been of considerable interest to many previous studies in strategic management (Palich, Cardinal, \& Miller, 2000; Mackey, Barney, \& Dotson, 2017; Subramaniam \& Wasiuzzaman, 2019), but it is apparent that the impact of diversification still generates much debate given the mixed findings (Palich et al., 2000; Volkov \& Smith, 2015). Some studies revealed that implementing a diversification strategy can adversely the performance affect (Zhou, 2011; Hashai, 2015; Gyan, 2017), which is in contrast to other studies that pinpointed how diversification strategies actually can improve the company performance (Kuppuswamy \& Villalonga, 2016; Chan, Bany-Ariffin, and Nasir, 2019).
One of the factors causing the differing research results is the use of variables that moderate the relationship between diversification and company performance (de Andrés, Fuente, \& Velasco, 2017). Among these factors is corporate governance, which includes the level of supervision and chief executive officer (CEO) performance (JaraBertin, 2015). In particular, diversification can cause a company's organizational structure to expand, which leads to higher information asymmetry. Such an issue poses great difficulty for coordination and supervision (Bushman, Chen, Engel, \& Smith, 2004; Rodríguez-Pérez \& Van Hemmen, 2010), decreasing the company's performance.

The increasingly complex coordination in companies with a broader organizational structure makes it vital to establish an effective coordina- 
tion function (Chandler, 1962). Coordination between all elements in a business entity is an essential determinant of the company's operational quality (Cha, Kim, Lee, \& Bachrach, 2015), and at a managerial level, the person responsible for executing the coordination function is top management or the chief executive officer. The greater the CEO's commitment to handling the coordination and supervision tasks at a company, the better is the coordination function. Likewise, the CEO's commitment to be involved in coordination across divisions determines the efficacy of diversification strategies.

Much of the research on diversification and firm performance originally stems from variousand at times contradictory-perspectives on diversification practices. One theory, for example, posits that a diversified company can cross-subsidize between segments, whereas another theory suggests that diversification may harm firm performance considering the motivation for such decisions-for example, management's opportunistic behavior (Volkov \& Smith, 2015). From the concept of economies of scale (Rumelt, 1974), diversification is observed to increase company performance, which was corroborated by Chan et al. (2019), who maintained that the optimal use of resources as a consequence of sharing of resources can help achieve economies of scale and ultimately improve company performance. However, in agency theory, diversification is argued to increase information asymmetry and coordination costs, which will reduce firm performance (Hernández-Trasobares \& Galve-Górriz, 2017).

Because of the opposing findings and theories regarding the actual impacts of diversification, this study sought to enrich the literature on the relationship between diversification and firm performance. In contrast to previous studies (Hernández-Trasobares \& Galve-Górriz, 2017; Chan et al., 2019), this study examined the direct effect of diversification strategies on company performance and the role of CEO commitment as the moderating variable. This study also analyzed both full sample and specific samples with different diversification levels, that is, those above and below the average level. Diversification levels in this study were measured using several diversification measurement methods, namely the entropy index, the Herfindahl index, and the number of segments. The purpose of using different measurement techniques was to test the data robustness. To provide a solid empirical contribution, this study used the panel data analysis method (i.e., balanced panel) to test the hypothesis. By combining both cross-section and time-series data, this method can thus eliminate any collinearity between variables, increase degrees of freedom, boost efficiency, and minimize bias (Gujarati, 2004).

\section{THEORETICAL BACKGROUND}

\subsection{Diversification and Firm Performance}

Diversification is a strategy used by companies to market their products, goods, or services for different segments (Ansoff, 1957). Companies commonly strive to expand their market segmentation by either creating new businesses and product types (Gyan, 2017) or enriching their product portfolios (Chan et al., 2019). Several aspects are considered when a company implements diversification strategies, such as the tendency to decrease market demand for the products, the bolstering of the company's competitive advantage, profit stability, technological developments, the allocation of retained earnings for investment, and risk distribution (Ansoff, 1957; Lizares, 2019).

Furthermore, diversification allows management to optimize the utilization of resources owned by the company. Resources include tangible resources such as production capacity, machinery, equipment, and other production facilities, as well as intangible resources such as management capabilities, company reputation, and information (Chartejee \& Wernerfelt, 1991). Prahalad \& Hamel (1990) stated that economies of scale can grow when companies use production factors concurrently for each business line.

Diversification of resources and activities can benefit companies because they then are able to take advantage of investment opportunities to create added value (Mackey, 2017). In the context of strategic management, diversification can increase the economic scope and synergy between business segments, strengthen the company's market power, carry out cross-subsidies, prevent 
predatory pricing, increase purchases and sales of products between segments, and create barriers to the potential entry of new competitors (Lewellen, 1971; Chan et al., 1989; de Andrés, Fuente, \& Velasco, 2017). These benefits likely will be optimized if management is able to allocate resources among existing businesses, allowing all segments to operate effectively and efficiently (Gyan, 2017).

Nevertheless, diversification may pose some threats to company performance, including changes in industry-specific risk, company size, number of businesses, or levels of relatedness of diversification (Chang \& Howard, 1989). The logical consequence of diversification is the formation of a new strategic business unit, which can cause the company's organizational structure to widen. This situation potentially can engender higher coordination costs and information asymmetry (Zhou, 2011; Hashai, 2015; Hernández-Trasobares et al., 2017; Parker-Lue \& Lieberman, 2020). According to agency theory, the latter may even lead to moral hazards and adverse selection (Gomariz \& Ballesta, 2014).

Another drawback of diversification strategies is that they will complicate coordination measures given the company's increasingly complex structure, which can result in high information asymmetry (Zhou, 2011; Hashai, 2015). In other words, the multi-divisional structure is an inevitable consequence when a company opts for a diversification strategy. Although such separation of structures typically is intended to reduce search and coordination costs in order to optimize market opportunities (Lien \& Li, 2013), they have some detrimental impacts on the firm performance. These negative outcomes may include complicated transactions, operational complexity, and information asymmetry, all of which will make coordination efforts more difficult (Bushman et al., 2004; Lien \& Li, 2013).

Given the contradictory perspectives on the influence of diversification on firm performance, this study proposes the following hypothesis to be tested:

H1: Diversification has a negative effect on firm performance.

\subsection{CEO Commitment}

It is suggested that corporate governance practices can minimize the adverse effects of diversification strategies on firm performance (Volkov \& Smith, 2015). In a diversified company, there usually is a need to establish separate divisions or strategic business units (SBUs) to handle different segments (Henderson \& Fredrickson, 2001). As a result, coordination becomes an important issue, especially at the highest level of the decision-making process. This process involves the board of directors, also referred to as the top management team, and their decisions in devising strategic policies have an impact on the company's performance (Sirén, 2018).

One of the key figures in the top management is the CEO, who plays a strategic role in realizing the vision and mission of the company, cultivating values by personally engaging in the development of systems and policies, and ensuring the implementation of these systems and policies (Keramati \& Azadeh, 2007; Miminoshvili, 2016). Top leaders have the task of formulating strategic policies in response to all situations that potentially can threaten the company's operations. They also have to oversee the allocation of resources, manage information that is relevant to the company, and resolve any internal conflicts. CEOs need to understand precisely the situation faced by the company using the information collected and processed by the members of top management (Sirén, 2018). Excellent coordination among different counterparts therefore is necessary to ensure the satisfactory completion of the duties.

The CEO can carry out the coordination function to overcome coordination problems stemming from the more complex organizational structure (Chandler, 1962). The CEO's commitment to handling the company's internal coordination plays a crucial role in increasing firm performance. Furthermore, the collaboration or coordination between departments, divisions, strategic business units, and functional areas is an essential determinant of the company's operational effectiveness (Cha et al., 2015). However, in reality, the CEO can be preoccupied with other commitments outside the company, which likely will damage the company's performance (Harymawan, Nasih, Ratri, \& Nowland, 2019). 
It is the responsibility of the CEO as the highest executive leader in the company to coordinate among the entire top management in managing the company. To do this successfully, the CEO needs to be involved in top management meetings in which the executives exchange information in order to proportion the company's capital among existing divisions more effectively. The importance of board meetings is evidenced further by the issuance of Regulation Number 33/POJK.04/2014 concerning the Board of Directors and Board of Commissioners of Issuers or Public Companies by the Indonesian Financial Services Authority. It is evident that top management meetings have received substantial attention owing to their roles in improving corporate governance. However, the significance of these coordination meetings, notably those attended by CEOs, has been relatively underinvestigated. Therefore, this study explored the extent to which the CEOs' involvement in such meetings influences firm performance. In line with earlier studies on the effect of corporate governance on firm performance (Liang, Kuo, Chan, \& Chen, 2020; Liu, 2019), this study took the view that CEOs' involvement in top management meetings mitigates the negative effect of diversification on firm performance.

Based on the preceding argument, this study proposes its second hypothesis:

H2: The relationship between diversification and firm performance differs between companies with high CEO commitment and those with low CEO commitment.

\section{METHODOLOGY}

The purposive sampling method was used to derive the required data, which consisted of a list of manufacturing companies obtained from the Indonesia Stock Exchange (IDX). A total of 76 firms, complemented by 912 firm-year observations collected in the balanced panel data set, were selected based on the period from 2007 to 2018 during which the firms were registered. The sample was limited only to companies that published their annual reports and audited financial reports.
These manufacturing companies operate in various sectors, such as basic industry, chemical industry, miscellaneous industry, and consumer goods industry. The selection of the manufacturing sector in this study was pertinent because of its significant contribution to the Indonesian economy. The manufacturing sector has the greatest number of companies registered on the IDX, and the sector's market capitalization is larger than that of other sectors. Given its prominence, it is important to study the influence of corporate strategies and the role of management in improving company performance in this sector.

Firm performance was measured using Tobin's $Q$, which was calculated with the equation from Kang, Anderson, Eom, \& Kang (2017). Tobin's $Q$ is equal to the sum of the book value of debt and market value of equity divided by the book value of assets $\left(\right.$ TOBINSQ $\left.=\frac{\text { book value of debt }+ \text { market value of equity }}{\text { book value of assets }}\right)$. To assess the degree of diversifications in a company, three main diversification measures are used, namely entropy, the Herfindahl index, and the number of segments (George \& Kabir, 2012; Lien \& Li, 2013; Chan et al., 2019). The entropy method (ENTROPY) was developed by Jacquemin \& Berry (1979) with the equation $D T_{i t}=\sum_{i=1}^{n}\left(P_{i}\right) \times \ln \left(\frac{1}{p i}\right)$.

This index indicates that the greater the value of DT, the higher is the level of diversification. Second, the Herfindahl index is calculated using the equation formulated by Hirschman (1964): $H E R F_{i t}=\Sigma\left(\text { Seg }_{i t}\right)^{2} / \Sigma\left(\text { Sales }_{i t}\right)^{2}$.

If the Herfindahl index ( $\mathrm{HHi}$ ) approaches 1 , the company is said to be more concentrated, whereas if the index approaches 0 , the company is said to be more diversified. The third measure of diversification is the logarithm of the number of segments (SEG). A larger number of segments denotes a higher degree of diversification in a company.

CEO commitment as a moderating variable is subject to the number of meetings attended by the CEO (CEOMEET), estimated by the natural logarithm of the number of top management meetings attended by the CEO. The use of proxies is grounded in the notion that coordination is an essential determinant in increasing the operational effectiveness of the company (Cha et al., 2015), implying that if the CEO is not committed to being involved person- 
ally in the coordination efforts, firm performance will be affected negatively (Keramati \& Azadeh, 2007; Harymawan et al., 2019).

Other variables were assessed in this study. One variable was company size, which was measured based on the logarithm of stock market value (Rand $\varnothing y \&$ Nielsen, 2002). The value indicates that the greater the stock capitalization, the higher is the firm performance. Another variable examined was the number of years the company was listed on the stock exchange (AGE), because older companies might have lower firm performance (George \& Kabir, 2012). Also taken into account was the reporting of loss (LOSS), using binary numbers, with 1 denoting the presence of loss reports and 0 otherwise. A company that reports a loss tends to have lower performance. The final variable was leverage (LEV), which is the total debt divided by the total assets (George \& Kabir, 2012). A high value of leverage indicates a higher level of performance. Considering all variables, the hypothesis testing used the following model:

TOBINSQ $_{i t}=\alpha_{0}+\alpha_{1}$ DIV $_{i t}+\alpha_{2}$ CEOMEET $_{i t}+\alpha_{3} D I V *$ CEOMEET $_{i t}$ $+\alpha_{4} S_{I Z E_{i t}}+\alpha_{5} A G E_{i t}+\alpha_{6} L_{O S S_{i t}}+\alpha_{7} L E V_{i t}$

In summary, the dependent variable of company performance was measured using Tobin's $Q$, whereas the independent variable was the diversification strategy (DIV), which was examined with three widely used measures in diversification studies (entropy, the Herfindahl index, and the number of segments). The moderating variable of CEO commitment (CEOMEET) was assessed using the natural logarithm of the number of meetings attended by the CEO. Other variables included company size, which was based on the natural logarithm of the market value of company shares ( $r$ ); company age, which was based on the number of years the company had been listed on the stock exchange (AGE); the reporting of loss (LOSS); and the value of leverage (LEV).

\section{RESULTS}

\subsection{Descriptive Statistics and Variable Correlations}

Winsorization was performed to treat the outlier data based on the average value criteria plus or minus a standard deviation of 2 . A normality test was conducted using the skewness value, with a value between 2 and -2 indicating that the data were normally distributed. The descriptive statistics of each variable are presented in Table 1.

Table 1: Descriptive statistics

\begin{tabular}{|l|c|c|c|c|c|c|}
\hline Variable & Max & Min & Mean & SD & N & Skew \\
\hline TOBINSQ & 5.680 & 0.600 & 1.696 & 1.353 & 912 & 1.784 \\
\hline ENTROPY & 1.739 & 0 & 0.461 & 0.425 & 912 & 0.582 \\
\hline HHi & 1 & 0 & 0.710 & 0.261 & 912 & -0.434 \\
\hline SEG & 10 & 1 & 2.794 & 1.570 & 912 & 1.273 \\
\hline CEOMEET & 4.277 & 0.693 & 2.589 & 0.621 & 912 & 0.022 \\
\hline SIZE & 33.941 & 18.380 & 27.813 & 2.311 & 912 & 0.100 \\
\hline AGE & 3.611 & 1.386 & 2.919 & 0.404 & 912 & -1.112 \\
\hline LEV & 1.278 & 0.132 & 0.525 & 0.269 & 912 & 0.820 \\
\hline LOSS & $0=84 \%$ & & & & & \\
\hline & $1=16 \%$ & & & & & \\
\hline
\end{tabular}

TOBINSQ $_{i t}=$ company performance, total debt, and market capitalization scaled by total assets of company $i$ in year $t$; DIV $_{\text {it }}$ = diversification of company $\mathrm{i}$ in year $\mathrm{t}$ (ENTROPY, HHI, and SEG); CEOMEET $_{\text {it }}=$ natural logarithm of the number of meetings attended by the CEO of company i in year $\mathrm{t}$; $\mathrm{SIZE}_{i t}=$ company size in the form of the natural logarithm of the market value of company $i$ shares in year $t$; $A G E_{i t}=$ company age, i.e., the number of years company $i$ had been listed on the stock exchange as of year t; LOSS $_{i t}=$ dummy variable: 1 if company $i$ in year $t$ reports a loss, and 0 otherwise; and $L_{E V}$ it = leverage, i.e., total debt divided by total assets of company $\mathrm{i}$ in year $\mathrm{t}$.

The average TOBINSQ was 1.1696 , meaning that the debt value and market value of the companies' shares was 1.696 times the total assets owned. The level of diversification was ENTROPY $=0.461$ and $\mathrm{HHi}$ $=0.710$, indicating that the diversification level was not too high. This finding is supported further by the low average number of segments, 2.794; the maximum number of segments was 10 . The average CEO attendance at top management meetings (CEOMEET) was 16.21272 ( $\log 7.265$ ) meetings/year. The maximum number of meetings attended by the CEO in a year was 72 , and the minimum was 2 . In addition, companies that reported losses (not reported in Table 1) accounted for $16 \%$ of the total observations.

There was a strong correlation between the variables used to measure diversification (ENTROPY, $\mathrm{HHi}$, and SEG) and company performance 
(Table 2). It is clear that diversification had a significant negative correlation with TOBINSQ. A strong correlation was observed between $\mathrm{HHi}$ and SEG with ENTROPY, but because these two variables were independent of each other in the three models, they were not part of the correlational analysis in this study. Furthermore, CEOMEET was found to have a positive correlation with TOBINSQ, corresponding to the variables of company size and company age, which also had a positive correlation with TOBINSQ.

\subsection{Hypothesis Testing}

Hypothesis testing in this study used panel data regression with a balanced panel. The Chow test, Breusch-Pagan Lagrange multiplier, and the Hausman test show how the data were processed using panel data with a random-effects regression model. Due to the problem of autocorrelation, obtaining a variant of constant error required a robust function in the statistical software STATA version 14. Table 3 displays the results of the panel data regression test. Company diversification had a negative effect on firm performance in all measurement models of diversification (entropy, Herfindahl index, and the number of segments) with a significance level of $0.05(\alpha=0.05)$. This supports the notion that higher levels of diversification correlate with lower levels of firm performance.
The number of CEO meetings (CEOMEET) was found to moderate the effect of diversification on firm performance in all size models of diversification: ENTROPY*CEOMEET and HHi*CEOMEET at $\alpha$ $=0.01$, and $\mathrm{HHI}{ }^{*}$ CEOMEET at $\alpha=0.10$. The effect of diversification on firm performance in companies with high rates of CEO attendance at top management meetings was different from that on those with low rates of CEO attendance. The empirical evidence shows how the presence of the CEO at the board of directors meeting can mitigate the negative effect of diversification on company performance.

From the internal capital market approach (Volkov \& Smith, 2015), the negative effect of diversification on company performance is attributed to the company's reliance on internal capital, which in turn reduces the supervision from external capital providers. This condition results in inefficient use of internal capital. As a consequence, the companies cannot optimize the use of corporate resources, whether tangible or intangible, when running different business lines. In contrast, collective diversification may allow companies to produce various products or services more optimally.

Regarding the CEO role, the results were consistent with those of previous studies that scrutinized CEO contribution to improving company performance (Fang, Wade, Delios, \& Beamish, 2007). These findings support the argument that

Table 2: Correlation coefficients between variables

\begin{tabular}{|c|c|c|c|c|c|c|c|c|c|}
\hline & TOBINSQ & ENTROPY & $\mathrm{HHI}$ & SEG & CEOMEET & SIZE & AGE & LOSS & LEV \\
\hline TOBINSQ & 1.000 & & & & & & & & \\
\hline ENTROPY & $-0.103^{*}$ & 1.000 & & & & & & & \\
\hline $\mathrm{HHi}$ & -0.035 & $-0.848^{*}$ & 1.000 & & & & & & \\
\hline SEG & $-0.121^{*}$ & $0.731^{*}$ & $-0.550 *$ & 1.000 & & & & & \\
\hline CEOMEET & 0.005 & $0.110^{*}$ & $-0.095^{*}$ & 0.033 & 1.000 & & & & \\
\hline SIZE & $0.503^{*}$ & $0.098^{*}$ & $-0.132 *$ & $0.164^{*}$ & $0.067^{*}$ & 1.000 & & & \\
\hline AGE & $0.226^{*}$ & $-0.130 *$ & $0.076 *$ & $-0.100 *$ & 0.033 & $0.320 *$ & 1.000 & & \\
\hline LOSS & -0.054 & $-0.135^{*}$ & $0.157^{*}$ & $-0.119 *$ & -0.042 & -0.221 & -0.049 & 1.000 & \\
\hline LEV & 0.001 & $-0.131^{*}$ & $0.132^{*}$ & -0.033 & -0.034 & -0.281 & $-0.080 *$ & $0.337^{*}$ & 1.000 \\
\hline
\end{tabular}


Table 3: Effect of diversification on firm performance

\begin{tabular}{|c|c|c|c|c|c|c|}
\hline \multicolumn{7}{|c|}{$\begin{aligned} \text { TOBINSQ }_{i t}= & \alpha_{0}+\alpha_{1} D_{I V}+\alpha_{2} \text { CEOMEET }_{i t}+\alpha_{3} D I V * C \text { CEOMEET } \\
& +\alpha_{4} \text { SIZE }_{i t}+\alpha_{5} \text { AGE }_{i t}+\alpha_{6} L_{O S S_{i t}}+\alpha_{7} L E V_{i t}\end{aligned}$} \\
\hline \multirow{2}{*}{ Variable } & \multicolumn{6}{|c|}{ Dependent variable: TOBINSQ } \\
\hline & Coefficient & P-value & Coefficient & P-value & Coefficient & P-value \\
\hline C & 0.540 & $0.020^{* *}$ & 0.870 & $0.000^{* * *}$ & 1.255 & $0.000 * * *$ \\
\hline ENTROPY & -1.440 & $0.000 * * *$ & & & & \\
\hline $\mathrm{HHi}$ & & & 1.808 & $0.015^{* *}$ & & \\
\hline SEG & & & & & -0.209 & $0.019 * *$ \\
\hline CEOMEET & -0.374 & $0.001 * * *$ & 0.224 & 0.111 & -0.345 & $0.010 * * *$ \\
\hline ENTROPY*CEOMEET & 0.458 & $0.002^{* *}$ & & & & \\
\hline HHi*CEOMEET & & & -0.585 & $0.015^{* *}$ & & \\
\hline SEG*CEOMEET & & & & & 0.057 & $0.0705^{*}$ \\
\hline SIZE & 0.367 & $0.000^{* * *}$ & 0.368 & $0.000^{* * *}$ & 0.369 & $0.000 * * *$ \\
\hline AGE & -0.120 & 0.278 & -0.114 & $0.000^{* * *}$ & -0.111 & 0.299 \\
\hline LOSS & 0.064 & 0.291 & 0.063 & 0.296 & 0.062 & 0.302 \\
\hline LEV & 1.116 & $0.000^{* * *}$ & 1.141 & $0.000 * * *$ & 1.148 & $0.000 * * *$ \\
\hline$R^{2}$ & 0.278 & 0.270 & 0.283 & & & \\
\hline PROB $>\mathrm{CHI}^{2}$ & 0.000 & 0.000 & 0.000 & & & \\
\hline $\mathrm{N}$ & 912 & 912 & 912 & & & \\
\hline
\end{tabular}

the coordination function performed by the CEO can indeed mitigate the adverse effects of information asymmetry caused by diversification strategies (Chandler, 1962). The coordination between SBUs can increase the effectiveness of company management (Cha et al., 2015), and in the case of a direct relationship, the CEO's commitment to actively participate in coordination activities through board meetings can increase the company's performance (Harymawan et al., 2019).

The empirical evidence shows that CEO commitment is a critical factor in improving company performance. Top leaders play an essential role in designing strategic policies, managing conflicts, making decisions to respond to changing business environments, and implementing diversification strategies. He high commitment can enhance the effectiveness of coordination between departments, divisions, SBUs, and the functional areas (Cha et al., 2015).

\subsection{Additional Analysis}

Additional testing studied the effect of diversification on company performance in companies with a high diversification level. In the model, a value of 1 represents companies with diversification values above the average level of diversification for all the observed companies, and 0 represents otherwise. The diversification variables (ENTROPY, HHi, and SEG) were multiplied by the dummy variable to determine which companies had diversification levels above the average value.

At the $5 \%$ significance level in all measurement models (ENTROPY, HHi, and SEG), high diversification had a negative effect on company performance (Table 4), confirming the first hypothesis (H1). Clearly, companies with a high level of diversification tend to have low performance. 
Table 4: Additional teting based on diversification above sample average value

\begin{tabular}{|l|c|c|c|c|c|c|}
\hline \multirow{2}{*}{ Variable } & \multicolumn{5}{|c|}{ Dependent variable: TOBINSQ } \\
\cline { 2 - 6 } & Coefficient & P-value & Coefficient & P-value & Coefficient & P-value \\
\hline C & 1.087 & $0.000^{* * *}$ & 0.979 & $0.000^{* * *}$ & 1.195 & $0.000^{* * *}$ \\
\hline HIGH_ENTROPY & -0.256 & $0.045^{* *}$ & & & & \\
\hline HIGH_HHI & & & 0.211 & $0.025^{* *}$ & & \\
\hline HIGH_SEG & & & & & -0.232 & $0.037^{* *}$ \\
\hline CEOMEET & -0.286 & $0.003^{* * *}$ & -0.065 & 0.158 & -0.299 & $0.007^{* * *}$ \\
\hline $\begin{array}{l}\text { HIGH_ENTROPY*CEOME } \\
\text { ET }\end{array}$ & 0.248 & $0.008^{* * *}$ & & & & \\
\hline HIG_HHI*CEOMEET & & & -0.232 & $0.014^{* *}$ & & \\
\hline HIG_SEG*CEOMEET & & & & & 0.234 & $0.014^{* *}$ \\
\hline SIZE & 0.366 & $0.000^{* * *}$ & 0.365 & $0.000^{* * *}$ & 0.373 & $0.000^{* * *}$ \\
\hline AGE & -0.118 & 0.282 & -0.122 & 0.274 & -0.139 & 0.259 \\
\hline LOSS & 0.064 & 0.294 & 0.054 & 0.323 & 0.079 & 0.323 \\
\hline LEV & 1.132 & $0.000^{* * *}$ & 1.130 & $0.000^{* * *}$ & 1.147 & $0.000^{* * *}$ \\
\hline$R^{2}$ & 0.280 & 0.271 & 0.278 & & & \\
\hline PROB > CHI & 0.000 & 0.000 & 0.000 & & & \\
\hline N & 912 & 912 & 912 & & & \\
\hline Note: See Table 1 for variable definitions. ${ }^{*}, * *$ & , and ${ }^{* * *}$ denote significance at $\alpha=10,5$, and 1 percent, respectively (one-tailed) \\
\hline
\end{tabular}

In the analysis of the effect of CEO commitment on the relationship between diversification and company performance in companies with a high diversification level, the results also were consistent with the second hypothesis, testing the three diversification measures. High CEO commitment can mitigate the adverse effects of diversification on a company's performance despite its high diversification levels.

\section{DISCUSSION AND CONCLUSION}

\subsection{Theoretical Contributions}

This study makes several theoretical contributions to the study of strategic management. First, this study provides more insights into the effect of diversification strategies on firm performance from the agency theory perspective (Zhou, 2011; Hernández-Trasobares \& Galve-Górriz, 2017). In particular, the findings show that diversification tends to harm corporate performance as tested in all measurement models (entropy index, Herfindahl index, and a number of segments). The higher the level of diversification, the more likely it is that companies will have higher information asymmetry and more-complex coordination efforts, thereby reducing firm performance. Diversification leads companies to create SBUs to manage a new business or manufacture new products, resulting in a wider organizational structure. As a consequence, business operations and information flows become increasingly more complex, which is likely to cause high information asymmetry, moral hazard, and adverse selection.

Second, when the effect of CEO commitment is considered, it is evident that frequent attendance of the CEO at top management meetings can attenuate the negative impact of diversification on company performance. Effective coordination between SBUs can mitigate information asymmetry and improve operational quality (Cha et al., 2015). These coordination efforts can en- 
courage more-effective and -efficient allocation of resources, create a more transparent and reliable flow of information, and reduce internal conflicts as each unit has its internal targets to achieve. Correspondingly, to enhance the company's performance, the presence of the CEO at coordination meetings of the board of directors becomes of considerable importance. These meetings can serve as the venue in which relevant information is coordinated and exchanged among the top management members, encouraging effective allocation of the company's resources across different divisions.

Another contribution of empirical nature of this study is its research methodology. Based on the panel data regression analysis (i.e., balanced panel), the results are consistent in both the full sample and the specific samples of companies whose levels of diversification are either above or below the average level.

\subsection{Practical Implications}

Regarding practical contributions to the field of strategic management, this study provides practitioners with insights essential to the implementation of diversification. Although diversification strategies can be beneficial to the improvement of company performance, they still pose potential risks. The varied range of control resulting from diversification practices requires an effective control mechanism to mitigate any moral hazard and adverse selection in the management of strategic business units. Optimal economies of scale from sharing resources, if not utilized properly, will have a negative impact on company performance. Therefore, an excellent managerial capability is needed in the management of sharing resources in a diversified company so that economies of scale can be achieved to the utmost extent.

Another implication is that in companies using diversification strategies, there is an increasing need for systematic coordination among the top management to improve firm performance. The coordination between different departments, divisions, and SBUs has been shown to contribute to operational effectiveness and to anticipate in- formation asymmetry, both of which can lead to better firm performance. Moreover, as one of the primary leaders, the CEO is expected to be involved in the coordination process by regularly attending high-stakes meetings. By doing so, the CEO actually demonstrates strong commitment to the tasks, which can mitigate any possible undesirable effects on company performance. Top management leadership in coordination efforts is an essential factor determining the effectiveness of a company's strategy. It is a key component of the success of any strategies adopted to improve firm performance.

\subsection{Limitations and future research}

Nonetheless, there are some limitations to this study that were not addressed. Firstly, when exploring the issue of diversification and firm performance, future researchers can examine several aspects that this study did not consider. One aspect is the nonlinear effect of diversification on company performance, which is said to be present in the relationship between the two variables (Palich et al., 2000). In relation to CEO commitment, the influence of share ownership also can be considered as one of the control variables in future studies. The last limitation is that the hypothesis testing was carried out using panel data regression. Future research can consider using a structural equation model to test the relationship between the variables simultaneously. 


\section{EXTENDED SUMMARY/IZVLEČEK}

Študija preučuje učinek strategij diverzifikacije na uspešnost podjetja in obseg, v katerem zavezanost glavnega izvršnega direktorja (CEO) ublaži to razmerje. Učinek diverzifikacije na uspešnost podjetja je bil analiziran $v$ vzorcu, ki je vključeval podjetja tako z nadpovprečno kot tudi s podpovprečno stopnjo razpršenosti. Vzorec je sestavljalo 76 proizvodnih podjetij, ki so kotirala na Indonezijski borzi (IDX) med letoma 2007 in 2018. Analiz je bila opravljena z uporabo regresije uravnoteženih panelnih podatkov. Tobinov $Q$ je bil uporabljen za merjenje uspešnosti podjetja, skupaj s tremi merili strategij diverzifikacije: indeksom entropije, Herfindahlovim indeksom in številom segmentov. Rezultati kažejo, da diverzifikacija vodi do nižje uspešnosti podjetja, medtem ko zavezanost generalnega direktorja odpravlja negativni vpliv diverzifikacije na uspešnost podjetja v vseh modelih merjenja (tj. entropija, Herfindahlov indeks in število segmentov). V skladu s tem so med podjetji tako z visoko ko tudi z nizko stopnjo diverzifikacije opazni negativni učinki strategij diverzifikacije in dosledne zavezanosti generalnega direktorja.

\section{REFERENCES}

Ansoff, H.I. (1957). Strategies for diversification. Harvard business review, 35(5), 113-124.

Bushman, R., Chen, Q., Engel, E., \& Smith, A. (2004). Financial accounting information, organizational complexity and corporate governance systems. Journal of Accounting and Economics, 37(2), 167-201.

Cha, J., Kim, Y., Lee, J.Y. \& Bachrach, D.G. (2015). Transformational leadership and inter-team collaboration: Exploring the mediating role of teamwork quality and moderating role of team size. Group \& Organization Management, 40(6), 715-743.

Chan, L.F., Bany-Ariffin, A.N. \& Nasir, A.B.M. (2019). Does the Method of Corporate Diversification Matter to Firm's Performance? In Asia-Pacific Contemporary Finance and Development. Emerald Publishing Limited.

Chandler, A. D. (1962). Strategy and structure: Chapters in the history of the American industrial enter-prise. Cambridge, MA: MIT Press.

Chang, Y., \& Howard, T. (1989). The Impact Of Diversification Strategy On Risk-Return Performance. Strategic Management Journal, 10(3), 271.

Chartejee, S. \& Wernerfelt, B. (1991). The Link Between Resources and Type of Diversification. Strategic management journal, 12(1), 33-48.

de Andrés, P., de la Fuente, G. \& Velasco, P. (2017). Does it really matter how a firm diversifies? Assetsin-place diversification versus growth options diversification. Journal of Corporate Finance, 43, 316-339.
Fang, Y., Wade, M., Delios, A. \& Beamish, P.W. (2007). International diversification, subsidiary performance, and the mobility of knowledge resources. Strategic Management Journal, 28(10), 1053-1064.

Gomariz, M.F.C. \& Ballesta, J.P.S., (2014), "Financial reporting quality, debt maturity and investment efficiency." Journal of Banking \& Finance, 40, 494-506.

George, R. \& Kabir, R., 2012. Heterogeneity in business groups and the corporate diversification-firm performance relationship. Journal of business research, 65(3), 412-420.

Gujarati, D. N. (2004). Basic Econometrics : Fourth Edition. The McGraw-Hill Companies.

Gyan, A.K. (2017). Moderating role of productivity on diversified conglomerates and performance: the case of Malaysia. Asia-Pacific Journal of Business Administration, 9(2), 118-133.

Hernández-Trasobares, A., \& Galve-Górriz, C. (2017). Diversification and family control as determinants of performance: A study of listed business groups. European Research on Management and Business Economics, 23(1), 46-54.

Harymawan, I., Nasih, M., Ratri, M.C. and Nowland, J. (2019). CEO busyness and firm performance: evidence from Indonesia. Heliyon, 5(5), p.e01601.

Hashai, N. (2015). Within-industry diversification and firm performance-An s-shaped hypothesis. Strategic Management Journal, 36, 1378-400.

Henderson, A.D. \& Fredrickson, J.W. (2001). Top management team coordination needs and the CEO pay gap: A competitive test of economic and behavioral views. Academy of Management Journal, 44(1), 96-117. 
Hirschman, A.O. (1964). The paternity of an index. Am. Econ. Rev. 54 (5), 761-770.

Jara-Bertin, M., López-Iturriaga, F.J. \& Espinosa, C. (2015). Diversification and control in emerging markets: The case of Chilean firms. BRQ Business Research Quarterly, 18(4), 259-274.

Jacquemin, A. P., \& Berry, C. H. (1979). Entropy measure of diversification and corporate growth. The Journal of Industrial Economics, 359-369.

Kang, H.C., Anderson, R.M., Eom, K.S. and Kang, S.K. (2017). Controlling shareholders' value, long-run firm value and short-term performance. Journal of Corporate Finance, 43, 340-353.

Keramati, A. \& Azadeh, M.A. (2007), Exploring the effects of top management's commitment on knowledge management success in academia: A case study. In Proceedings of World Academy of Science, Engineering and Technology (Vol. 21).

Kuppuswamy, V. \& Villalonga, B. (2016). Does diversification create value in the presence of external financing constraints? Evidence from the 2007-2009 financial crisis. Management Science, 62(4), 905-923.

Lewellen, W.G. (1971). A pure financial rationale for the conglomerate merger. The journal of Finance, 26(2), 521-537.

Liang, H.Y., Kuo, L.W., Chan, K.C. \& Chen, S.H. (2020). Bank diversification, performance, and corporate governance: evidence from China. Asia-Pacific Journal of Accounting \& Economics, 27(4), 389-405.

Lien, Y. C., \& Li, S. (2013). Does diversification add firm value in emerging economies? Effect of corporate governance. Journal of Business Research, 66(12), 2425-2430.

Liu, TK. (2019). Corporate Social Responsibility, Corporate Governance and Business Performance of Non-Financial Industry. International Journal of Economics and Business Administration, Volume VII, Issue 3, 260-278.

Miminoshvili, M. (2016). The leadership role in the organizational culture change at local self-government institutions. Dynamic Relationships Management Journal, 5(2), 49-67.

Mackey, T.B., Barney, J.B. \& Dotson, J.P. (2017). Corporate diversification and the value of individual firms: $A$ Bayesian approach. Strategic Management Journal, 38(2), pp.322-341.

Palich, L.E., Cardinal, L.B. \& Miller, C.C. (2000). Curvilinearity in the diversification-performance linkage: an examination of over three decades of research. Strategic management journal, 21(2), 155-174.

Parker-Lue, S., \& Lieberman, M. (2020). The impact of diversification on task performance: Evidence from kidney transplant centers. Strategic Management Journal, 41(7), 1169-1190.
Prahalad, C.K. \& Hamel, G. (1997). The core competence of the corporation. In Strategische Unternehmungsplanung/Strategische Unternehmungsführung ( $p p$. 969-987). Physica, Heidelberg.

Rand $\varnothing y$, T. \& Nielsen, J. (2002). Company performance, corporate governance, and CEO compensation in Norway and Sweden. Journal of Management and Governance, 6(1), pp.57-81.

Rumelt, R.P. (1974). Strategy, structure, and economic performance.

Sirén, C., Patel, P.C., Örtqvist, D. \& Wincent, J. (2018). CEO burnout, managerial discretion, and firm performance: The role of CEO locus of control, structural power, and organizational factors. Long Range Planning, 51(6), pp.953-971.

Subramaniam, V. \& Wasiuzzaman, S. (2019). Geographical diversification, firm size and profitability in Malaysia: A quantile regression approach. Heliyon, 5(10), p.e02664.

Rodríguez-Pérez, G. \& Van Hemmen, S. (2010). Debt, diversification and earnings management. Journal of Accounting and Public Policy, 29(2), 138-159.

Volkov, N.I. \& Smith, G.C. (2015). Corporate diversification and firm value during economic downturns. The Quarterly Review of Economics and Finance, 55, 160-175.

Zhou, Y. M. (2011). Synergy, coordination costs, and diversification choices. Strategic Management Journal, 32(6), 624-639. 